\title{
Policing Environmental Injustice
}

\author{
Andrea Brock and Nathan Stephens-Griffin
}

\begin{abstract}
Environmental justice (EJ) activists have long worked with abolitionists in their communities, critiquing the ways policing, prisons, and pollution are entangled and racially constituted (Braz and Gilmore 2006). Yet, much EJ scholarship reflects a liberal Western focus on a more equal distribution of harms, rather than challenging the underlying systems of exploitation these harms rest upon (Álvarez and Coolsaet 2020). This article argues that policing facilitates environmentally unjust developments that are inherently harmful to nature and society. Policing helps enforce a social order rooted in the 'securing' of property, hierarchy, and human-nature exploitation. Examining the colonial continuities of policing, we argue that EJ must challenge the assumed necessity of policing, overcome the mythology of the state as 'arbiter of justice', and work to create social conditions in which policing is unnecessary. This will help open space to question other related harmful hegemonic principles. Policing drives environmental injustice, so EJ must embrace abolition.
\end{abstract}

Keywords state violence, political ecology, environmental justice, policing, abolitionism, animal liberation, ecocide.

\section{Introduction}

Environmental and climate justice ${ }^{1}$ movements and scholarship are proliferating across the world. The environmental justice (EJ) Atlas now documents 3,455 EJ conflicts that include struggles over industrial agriculture, dams, mining, infrastructure projects, deforestation, biomass, and much more (Scheidel et al. 2020; Temper et al. 2020). Many of these are violently policed by military and police forces, private security services and militias, to enforce ecologically destructive projects and programmes. Yet, Álvarez and Coolsaet (2020) have argued that EJ scholarship tends to focus on the inequitable distribution of environmental harm and benefits associated with these projects, rather than challenging the underlying system and ideology of exploitation, extraction, human-nature relations, capitalism, and colonial continuities. 
[N]otwithstanding the suitability of distributive solutions in the context of toxic pollution or hazardous waste, for example, environmental equity is intrinsically linked to an idea of environmental exploitation. What it tells us is that this exploitation does not necessarily need questioning as long as its most harmful effects are being distributed equitably within society. (ibid.: 6)

This exploitation, we argue, is linked to a hierarchical socialecological ordering that is secured and enforced through policing. Abolitionist campaigns seek to reduce or eliminate police and other related carceral institutions like prisons. While many environmental and climate justice scholars and activists critique the violent - often deadly - policing of specific struggles against megaprojects, abolition has not been widely embraced as a core objective of mainstream EJ, ${ }^{2}$ which has tended towards liberal reformism (Dunlap 2021). This is despite the radical roots of the concept of $\mathrm{EJ}$ in the black civil rights movements and the Black Panther Party, championed by black people, Latinx, indigenous peoples, and Asian Americans (Perkins 2021).

Critical scholarship has highlighted the ways in which policing supports and maintains a white supremacist, patriarchal, capitalist, ecocidal global social order (Elliott-Cooper 2021; Roy 2021; Neocleous 2021; Brock and Stephens-Griffin, forthcoming3). Central within this is the defence of property rights, through enclosures and exclusions; the right to kill non-humans; and the right to exploit, extract, and degrade ecosystems. Current logics of policing are therefore intertwined in the history of industrialism and capitalist development, colonial and imperial histories and continuities, and counter-insurgency operations (Verweijen and Dunlap 2021). Policing also functions through

techniques of social control; indirectly through surveillance, but also through the work of bureaucratic and legal institutions and government departments, schools and universities, media, charities, and other organisations that are enrolled in various ways to regulating people's ideas, behaviour, mobility, wellbeing, and access to financial and other forms of support. (Brock and Stephens-Griffin, forthcoming)

In this article we argue that policing facilitates forms of industrial development and globalisation that are environmentally unjust and inherently harmful to nature and human society. In other words, policing drives environmental injustice. For this reason, EJ must embrace abolitionist principles which seek to create the social conditions in which policing is no longer necessary (Lamble 2021). This will, in turn, help to open up space to question the primacy of economic growth and the very nature of ownership; the notion of nature and animals as property; the right to kill and the right to degrade; and hegemonic anthropocentric modes of thinking and how these connect to logics of white, male supremacy. 
To illustrate the relationship between policing and environmental injustice, we focus on policing in and by Imperial Britain. We start by briefly sketching out the relationship between colonialism, capitalism, patriarchy, and policing. We then explore the policing of environmental and climate injustice (enforcing extractivism and ecocide), the policing of 'green capitalism' (the securing of socially and ecologically unjust projects under the name of conservation or climate mitigation), and the policing of the right to kill (through animal agriculture and hunting). We conclude by appealing to EJ scholars and activists to form alliances with, and work towards abolition of policing, prisons, and carceral logics of punishment and containment in society.

\section{Policing and EJ}

Policing is historically rooted in state management of populations for the maintenance and preservation of an existing social order via diverse means, so our understand of policing should not be limited to the formal institutions of 'the police' (Neocleous 2021). Policing is enacted by uniformed and undercover state police and military organisations, corporate security contractors, paramilitary organisations, through coercive maintenance of public order and surveillance practices, as well as more indirectly through bureaucratic and legal institutions, including schools, universities, and media apparatus (Reiner 2010). ${ }^{4}$ Together, these interconnected dimensions of policing ensure the continuation of an ecologically and socially disastrous condition of 'permanent war' (Dunlap 2014), against human and non-human populations and ecosystems. Policing helps enforce a social order that is rooted in the 'securing' of property, hierarchy, and human-nature exploitation and serves to extend the 'current intensification of internal colonisation' (ibid.: 53) in the name of progress, security and safety, and 'high-modernist ideology' (Scott 1998). EJ scholars and movements need to take these seriously and overcome the mythology of the state as 'arbiter of justice' or manager of environmental goods and bads (Dunlap 2020).

Álvarez and Coolsaet (2020) have argued that while most empirical EJ work is being carried out in the global South, conceptual EJ work continues to be dominated by Western academia and defined through Western ways of thinking 'bound to a hegemonic-Western idea of modernity and Westerninspired political ideals (e.g., solutions to injustices are conceived within the realm of the state)' (ibid:: 7). The lack of critique of policing speaks to this point. Policing is inherent to statism and state power (Neocleous 2021), which is itself part and parcel of coloniality (Ramakrishna 2014). Policing facilitates Western forms of power in non-Western societies to control and exploit human labour as well as nature (in the form of 'resources') (Quijano 2000). In turn, it structures 'the relationships between peoples and nature, and among the former in regard to the latter, especially with regard to the ownership of the resources of production' (Quijano 2014: 286, translation cited in Álvarez and Coolsaet). 
To challenge environmental injustice not just as an inequitable distribution of harms and goods, but to break with the underlying practice and ideology, EJ scholars and activists should critique and break with the logic of policing as an assumed necessity. Some EJ activists have long worked with abolitionists in their local communities (Braz and Gilmore 2006), and the concept of 'toxicity' has been central to EJ campaigning as well as police and prison abolitionism (Thompson 2018: 9). The diverse harms associated with policing, prisons, and pollution disproportionately affect people of colour, especially those living in urban communities, as political ecology scholars Pulido and De Lara (2018) have demonstrated.

As Dunlap has argued, 'the inherent liberalism within EJ studies serves to discipline mentalities and, potentially, act as a pacification device' (Dunlap 2021: 7). To stop and subvert ecological injustices and build healthy human (and) ecological communities, we call on EJ activists and scholars to work with - and to build - abolitionist alternatives and solutions. This opens the door for much more serious collaboration and joining of struggles based on solidarity across autonomous action and ecological self-defence and other attempts to create a more just future world through our actions in the present. Abolition provides a route to these aims and should ultimately be a productive process; it should focus on creating and building alternatives as opposed to simply removing carceral institutions (Davis 2005). As Kaba (2021: 2-3) argues: 'abolition is a positive project that focuses, in part, on building a society where it is possible to address harm without relying on structural forms of oppression or the violent systems that increase it'. For Gilmore (2020, cited in Lamble 2021: 148) 'abolition is about abolishing the conditions under which prison became the solution to problems, rather than abolishing the buildings we call prisons'. We therefore aim to contribute to EJ by encouraging the building of bridges and solidarity between EJ and abolitionist struggles. The importance of these bonds of solidarity comes into sharper focus when placing policing in its historical context.

\section{Policing colonialism, capitalism, and patriarchy}

The logic of policing is deeply entangled with colonialism, extractivism, patriarchy, and environmental harm. Historically, Britain's violent colonial endeavours have rested on the creation and enhancement of policing techniques, as illustrated by 'laboratory theories' of policing (Arendt 1951; Ramakrishna 2014). Acknowledging this is central to understanding the role of policing as a contemporary driver of environmental injustice.

Historically, Britain employed various methods and modes of policing, and worked with private chartered companies to develop extractive industries in colonised nations and to repress opposition (e.g. the British South Africa Company) (Verweijen and Dunlap 2021; Abrahamsen and Williams 2011). British domestic 
penal policy also functioned to establish and entrench its colonial power abroad, such as through 'transportation' - the practice whereby so-called 'criminals' were deported to British colonies to provide cheap labour (Maxwell-Stewart 2010). This frequently also had a huge ecological impact, for example, through building new roads, bridges, other infrastructure, and agriculture. British colonialism and its harmful ecological effects relied heavily on policing and domestic penal policy (Redfield 2005).

Plantations and plantation slavery were key to the development of global capitalism. They provided a space to develop and experiment with modern scientific management techniques, and represented a lucrative source of income for British development at home (Johnson 2013). It is often assumed that the formal establishment of the police in Britain came after the abolition of slavery but, in reality, there was overlap (Bowling, Reiner and Sheptycki 2019). English colonists developed slave codes that were enforced by incipient forms of policing to uphold 'iniquitous social relationships' across North America and the Caribbean throughout the seventeenth and eighteenth centuries (ibid.: 131). Vitale (2017) argues that slave patrols should be understood as a precursor to contemporary forms of policing. Slavery, upheld by policing, was central to the expansion of tobacco and cotton agriculture, demonstrating the ways that Britain's involvement in slavery influenced policing in colonised nations and their ecologies (Kappeler 2014).

Domestically, institutions of policing emerged in Britain as a means of controlling people in the newly expanding urban centres, especially following the industrial revolution. As Whitehouse (2014) puts it: police were 'a response to crowds, not crime'. According to Foucault (2007 [1978]) the emergence of the police accompanied new forms of 'regulatory practice' of power, which sought to control populations. The policing of access to and exploitation of nature was crucial, and closely linked to the great formal 'enclosure' movements of the sixteenth century onward; these saw a radical transformation of British society whereby previously public land went into private ownership (Bookchin 1982).

Orthodox histories of British policing have tended to consider domestic and colonial policing separately from, and in isolation of, one another. This is problematic not least because, as Sinclair and Williams (2007: 221) argue: 'empire has never been a one-way process'. They point to the large numbers of British chief constables recruited from Ireland during the interwar period as evidence the 'cross-fertilisation' of 'colonial' and 'domestic' policing in Britain. This contradicts the orthodox histories of policing which see colonial policing as distinct and more 'punitive' than 'consensual' policing at home. Then Ireland Secretary Robert Peele experimented with policing in Dublin, developing a professionalised, semi-armed police force to enforce the colonial order (Woodman 2020). Peele became Home Secretary 
shortly after, and this colonial experiment acted as the model for his establishment of the London Metropolitan Police in 1829 (Brogden 1987; Woodman 2020). Chowdhury (2021) further explores the relationships between British policing at home and in the places it colonised in terms of a 'Colonial Boomerang', locating contemporary racialised policing in the UK within a multidirectional movement of policing cultures and techniques between colonies and metropole. These ideas link back to the work of Hannah Arendt, in particular the 'laboratory hypothesis' in which European Imperialism acted as a laboratory for racial doctrines and practices domestically (Arendt 1951). Elliott-Cooper (2021) explores how contemporary state power reproduces racialised forms of violence via contemporary policing, which are in many cases deeply connected to British colonial legacies, including counter-insurgency operations to repress anti-colonial resistance and ensure exploitation of resources. As JosephSalisbury, Connelly and Wangari-Jones (2021) has demonstrated, institutional racism is endemic and pervasive in Britain, manifesting at every level of policing from stop and search, to arrest, prosecution, sentencing, rates of imprisonment, through to deaths in/after custody. In Britain, black people are almost ten times more likely to be stopped and searched than white people, and seven times more likely to be tasered by police (ibid.). Since 1990, there have been 1,796 deaths in custody or otherwise following contact with the police - a statistic in which non-white people 'die disproportionately as a result of use of force or restraint by the police' (Inquest 2020). Contemporary racist policing has been a tool to protect the wealth and profit generated through colonial-extractivist processes, which in turn helps to consolidate the dehumanisation of colonised peoples, and the oppressive systems of power and hegemony that drive ecocide. Policing is fundamental to the ongoing extractivist British Imperial project.

Radford and Stanko (1994: 149) argue that 'sexual [gendered] violence is used by men to maintain relations of male dominance and female subordination, which are central to the patriarchal social order'. Just as the above enduring legacies of colonialism persist in racialised policing today, contemporary policing also rests on a foundation of institutional misogyny embedded within a wider patriarchal context, that is again tied to maintenance of a hierarchical social order. These dynamics of institutional sexism came to prominence recently with the murder of Sarah Everard by a serving police officer, and the subsequent police brutalisation of women holding a peaceful vigil in her memory. Townsend and Heal (2019) reported that between 2015 and 2018 UK police officers and staff were reported for alleged domestic abuse almost 700 times, with only 3.9 per cent of police officers being convicted (a rate 2.3 per cent lower than for the general population). Stephenson (2021) reported that an average of one woman a week comes forward to report that their partner in the police is abusing them or their children, with more than 125 women having come forward in the last two years. A culture 
of dismissiveness, protectiveness over abusers and cover-ups pervades. We might also look to the 'spycops' scandal to further illustrate the institutional sexism of the police whereby undercover police deliberately coerced female activist targets into long-term romantic and sexual relationships (Lubbers 2012). The subsequent Covert Human Intelligence Sources Act (2021) makes it legal for undercover agents to commit crimes, including coercing people into relationships on false pretences. This is notable in clearly illustrating the gendered abuse of environmental, animal rights, and racial justice movements by an institutionally racist and sexist police establishment - bringing the connections between policing and environmental injustice into sharp relief.

\section{Policing environmental and climate injustice - pushing extractive frontiers}

Policing is key to environmental and climate injustice and pushing extractive frontiers. With extractivism, we here refer not only to the mining of resources, but the underlying colonial ideology that is bound to state power and serves as a mechanism of (neo)colonial 'plunder and appropriation' (Acosta 2013: 63; see also Willow 2016). It underlies the expansion of agricultural monocultures as much as logging operations and dam building, sucking not just value but life out of ecosystems and communities.

Many of the thousands of struggles ${ }^{5}$ against extractive projects and development are harshly policed, often involving various forms of intimidation, death and rape threats, physical violence, and even killing. In the UK, police enter 'public-private security partnerships' (Brock 2020) with private security forces and bailiffs to defend destructive projects like opencast coal mining, fracking, nuclear weapons, road building, animal exploitation, and hunting. They share mass intelligence and collaborate on the ground. Responses to ecological resistance reveal a 'stateextraction-ecocide nexus', whereby the political ecological order is maintained through statism, via direct repression, bureaucracy, counter-insurgency, public relations campaigns, and more (ibid:; see also Mason and Askins 2012; Stephens-Griffin et al. 2021; Brock and Dunlap 2018).

Environmental activists face gendered and racialised violence and repression from police. This manifests in public order policing of protest and direct action, undercover infiltrations, intelligence gathering, and more sophisticated psychological operations, divide-and-rule tactics, and counter-insurgency efforts (Brock 2020; Lubbers 2012). Work is often outsourced to private bodies including the 'National Eviction Team', whose involvement is characterised by particular disregard for protesters' health and safety. Policing further involves the imposition of civil injunctions on environmental defenders to prevent otherwise legal protest, unlawful arrests, and lengthy custodies for minor or non-arrestable offences, arrests as intelligence-gathering tools to collect fingerprints or DNA, or the imposition of restraining 
orders against protesters despite not being found guilty of a crime. Other parts of the (welfare) state and the benefits system have also been used as a weapon against activists, as shown in the use of the label 'panseed' ('politically active - not seeking employment') during the anti-roads movement in the 1990s, or more recently police passing on details of disabled fracking protesters to the Department for Work and Pensions in an effort to undermine their disability benefits claims (Rahim 2018). Environmental and animal liberation campaigning has further become part of the government's Prevent programme, requiring schools, universities, and health services, among others, to notify the government about potential radicalisation of campaigners 'to prevent people from being drawn into terrorism' (UK Government 2015; see Brock 2020). Academics (including the authors of this piece, employed by British universities) and medical professionals thus have a duty to partake in surveillance and policing of environmental (justice) struggles. As mentioned above, policing of behaviour and tactics further involves self-policing of movements, as the insistence of Extinction Rebellion on non-violence illustrates, or through the adoption of action consensus that sets a framework for acceptable action during climate or anti-coal camps, for instance.

British security services - including private security companies like Aegis and G4S - army forces, and corporations are - and have historically been - involved in environmental and land struggles across the world, in mining projects, oil and gas extraction and transport, industrial agriculture, chemical industries, logging, dam building, and other activities (see Brock and Stephens-Griffin, forthcoming; Abrahamsen and Williams 2011). The activities of these forces typically involve the dispossession and displacement of communities as well as the repression of resistance against extraction, exploitation, and degradation. The British Army also trains other armies that are employed to secure mining operations; for example, British-trained MONUSCO${ }^{6}$ soldiers in the Democratic Republic of the Congo, who train 'mining police' to protect coltan and gold mining (Selwyn 2020). The British military and private security firms protect fossil fuel exploration and transport by providing security for private corporations that seek to invest and extract oil and gas - in Iraq, resource-rich northern and western Africa, and elsewhere. Private companies also spy on protesters, with firms such as G4S even publishing information about campaigners in the UK on its website (G4S 2020). Policing thus directly contributes to environmental injustice.

\section{Policing 'green capitalism'}

As we have seen, policing is integral to industries associated with environmental injustice. However, many new and emerging extractive and infrastructure frontiers are packaged and framed as 'green', 'renewable' or 'sustainable', despite ecologically and socially disastrous effects on the ground: renewable energy projects, dam projects, national parks, and 'green 
infrastructure projects' such as high-speed train lines and electric infrastructures. Plenty of evidence shows that such projects come at significant environmental and social costs - including biodiversity loss and loss of livelihoods through monoculture plantations that are meant to act as carbon sinks, dam projects to generate 'clean' energy but that damage fish grounds and habitats, or the extractive operations required for so-called 'renewables' - or they simply displace ecological damage to other areas (Sovacool 2021; Temper et al. 2020). Dunlap (2019) shows this in relation to wind farms in Mexico that profit multinationals but harm local communities. Similar dynamics can be observed on indigenous Lenca territory in Honduras (EJ Atlas), or solar energy facilities in Greece (Argenti and Knight 2015; Siamanta 2019). Often, they hurt most those who have long looked after their local ecosystems, fighting extractive, logging, and other industrial projects - indigenous communities, smallholders, and communities who are being dispossessed or displaced, while profiting transnational or state investors and corporations.

In his review of the social and ecological impacts of hundreds of renewable energy and other mitigation projects, Sovacool (2021: 1) illustrates the 'enclosure (capture of land or resources), exclusion (unfair planning), encroachment (destruction of the environment), or entrenchment (worsening of inequality or vulnerability)' inherent in these projects. Across the world, communities are resisting these injustices, land grabs and dispossession pursued in the name of 'green capitalism', conservation, or 'sustainability'. This is where policing comes into play; enforcing and protecting property rights and economic activities through police, militaries, private security services, narco groups, and mercenaries employed by British companies.

In Britain, the best contemporary example to illustrate this is the ongoing and violent policing of anti-HS2 protesters. The British Government's HS2 high-speed railway project to connect London to the north of the country is framed to provide an ecological alternative to aviation and car transport, lowering carbon emissions from transport, and reducing air travel. The project claims to 'help the UK to tackle climate change and the drive to reach net zero carbon emissions' (HS2 2021). Meanwhile, ecologists and campaigners have exposed the huge ecological and social costs of the project, including the partial destruction of more than 100 ancient woodlands, the release of 11 million tonnes of carbon, and the irreparable damage to ecosystems and human communities. Environmental defenders occupied and set up camps in dozens of woodlands, taking direct action, digging tunnels, and organising demonstrations against the project. HS2 policing allowed for the cutting of trees and destruction of ecosystems and was characterised by violence against protesters by Thames Valley police and the private National Eviction Team. Numerous injuries of campaigners and endangering, racialised 
violence (Griffin 2020) and intimidation were documented by the human rights organisation Not1More, including,

violence, at the hands of the police, security and bailiffs, incidents included splitting scalps, and choking protestors in front of helpless onlookers... years of harassment in the form of unfounded charges that are eventually dropped, to shattered bones and broken limbs, to degrading treatment of people with disabilities.

(N1M 2020; see also Taylor 2021)

Meanwhile, wildlife laws are very badly implemented and frequently ignored, not only by HS2 contractors but more generally in the UK: described as a system 'consisting of legislation inadequate to the task of wildlife protection, subject to an equally inconsistent enforcement regime... that fails to address the specific nature of wildlife offending' (Nurse 2013: 4).

Policing green capitalism further involves the policing of anti-mining resistance to ensure the provision of rare earth metals and 'green' technologies including e-mobility and renewables. Examples of this include police abuse and torture of Mapuche peoples in order to repress their resistance to hydropower in Chile (Carruthers and Rodriguez 2009); Rio Tinto's use of police and private security to repress resistance to its mining operations and enforce eco-tourist developments and other biodiversity mitigation strategies in Madagascar (Kill and Franchi 2016; Huff and Orengo 2020); the use of undercover policing and military forces to repress opposition, and the use of illegal police detection in industrial wind farm development, including development on indigenous land in Mexico (Dunlap 2019; Avila-Calero 2017).

Environmental injustice further manifests in militarised conservation or 'green militarisation', the 'extension of military approaches, personnel, equipment, techniques, partnerships and technologies to wildlife conservation' (Ashaba 2020: 1). The Jewish National Fund, a parastatal organisation and environmental charity in Israel that enforces the colonisation of Palestinian land for the establishment of national parks or forests, is one example of this logic.? While militarised conservation approaches stem from the 1980s, the past decades saw a growing presence of (foreign) military and paramilitary actors and armed technologies in conservation - especially in African countries - as the international wildlife trade has been gaining more international attention. The war for biodiversity has become, some argue, 'war, by conservation', framed to serve the protection of biodiversity, grounded in the narrative of 'poachers-as-terrorists', but driven by concerns about global security (Duffy 2016). Meanwhile, the involvement of police forces, militaries, and customs agencies in illegal wildlife trade has been documented in different places (e.g. Wyatt 2009). 
The British state is involved in wildlife and conservation policing across the African continent. A new $£ 900,000$ British military counter-poaching task force (Forces Net 2018) is involved in anti-poaching operations in Uganda and Malawi, for instance, and has previously trained anti-poaching units in Gabon (MoD 2019) and South Africa (Forces Net 2018), not least to secure the existence of wildlife for the 'thousands of tourists a year hoping to catch a glimpse of an elephant or a rhino in its natural habitat' (MoD 2019). Private armed 'eco-guards' are often recruited from police forces (Neumann 2004). Private British foundations run national parks with militarised guards, including the Virunga National Park in the Democratic Republic of the Congo, and The Prince of Wales's charitable body supports British forces training Malaysians in anti-poaching techniques to help protect endangered wildlife species like the tiger (Express and Star 2017). New military surveillance technologies monitor human and non-human populations. Anti-poaching policing has a long history - fortress conservation was used as a form of counterinsurgency in colonial Indonesia (Minarchek 2020) and militarised conservation has historical roots in the colonial era, especially the British conquest of sub-Saharan Africa (Neumann 2004). And yet, militarised conservation fails to actually protect biodiversity while exacerbating environmental injustice, as it does not challenge the underlying and more systemic drivers of wildlife loss: extractivism, large-scale logging, agribusiness, inequalities, and poverty.

In effect, policing green capitalism pushes the frontiers of capital(ism) and state control, making nature and humans manipulable (Scott 1998), enhancing the frontiers of capital, extractivism, and (eco)tourism.

\section{Policing the right to kill}

Coupled with the extractive enclosure of land and the right to exploit ecosystems therein, policing also protects the right to kill and exploit non-human animals helping maintain the human/ non-human hierarchies upon which the animal-industrial complex rests (Twine 2012). Gillespie and Narayan (2020: 3) argue that non-human subjects have 'long been entangled with global cultural politics of nation-building and nationalism'. It is well documented that non-human animals were used in colonial projects, for example, through the mass slaughter of the buffalo to control and eliminate indigenous peoples in North America (McGinnis 1990), and the use of domesticated farmed animals to colonise vast swathes of indigenous land, a process that has been described as 'animal colonialism' (Cohen 2017: 268).

It is important to problematise the historic and contemporary domestication and alienation of humans and non-humans, as well as subordination and ownership, which 'laid the foundation for social hierarchy as property and power emerged' (Various 2014: 8). This subordination allows for the exploitation and killing of non-human animals, which is profoundly socially and ecologically 
harmful (Pellow 2014). Aside from the harm to non-human animals themselves, who suffer immensely (Cudworth 2015), this exploitation is also harmful to human society and public health: for example, through links between animal industries and zoonotic diseases (Dalton 2021); increasing anti-microbial resistance, and other health implications (Losasso et al. 2018), as well as harms to human workers exploited in animal industries (Milmo, Heal and Wasley 2018). Furthermore, animal industries are harmful to the planet and the global climate - exacerbating climate and environmental injustice (Grossi et al. 2019). These multiple dimensions of harm are entwined with market dynamics, with animal industries embodying capitalist exploitation at its most ruthless (Nibert 2017; Twine 2012). Efforts to push back against exploitation of non-human animals are frequently met with extreme resistance and police repression, as the violent policing of hunt saboteurs and other animal liberation activists shows. This may be because efforts to liberate non-human animals pose a threat not just to profit and capital, but to the perceived superiority of humans within an anthropocentric social order.

We now examine the political role of the police through a brief study of the Stop Huntingdon Animal Cruelty (SHAC) campaign, which reveals the varied, interacting techniques of policing used to eliminate the campaign. SHAC was a high-profile anti-vivisection campaign formed in England in 1999, which sought to stop animal exploitation by Huntingdon Life Sciences (HLS), one of the world's largest non-clinical contract research organisations. Prior to the formation of SHAC, a Channel 4 News investigation into the treatment of animals at HLS showed staff exhibiting physical violence towards dogs and puppies, in addition to what many saw as the inherent violence of experimentation that animals were already undergoing. From its conception, SHAC's campaign was radical, uncompromising, and unapologetic. SHAC targeted not just HSL, but also businesses that HLS had dealings with. As a result of the campaign, numerous companies cut ties to HLS, and, at one point, HLS found itself without a bank account or insurer, leading the UK government to step in to provide them with both. In 2009, HLS had to go private due to the effectiveness of targeting shareholders (Mansell 2009).

The majority of SHAC's campaigning aimed to apply economic pressure to HLS thus removing the financial incentives of animal exploitation. Much of this campaigning was lawful and non-violent in nature. However, while often maintaining their innocence, SHAC campaigners have been accused of, and successfully prosecuted for, a range of unlawful and violent tactics, including physical violence against HLS' managing director (BBC 2001), attempted blackmail of HLS employees (BBC 2014), and the sinking of a shareholder's yacht (Posłuszna 2015). In this sense, the SHAC campaign transgressed a prevailing doctrine of non-violence within social movements (Gelderloos 2007). The police and HLS 
saw SHAC as a 'domestic extremist' or 'terrorist' organisation and collaborated to eliminate the campaign entirely. Tactics deployed against SHAC were varied, including typical public order policing; the use of covert surveillance; the imposition of strict bail and later parole conditions throughout the course of activists being arrested, bailed, charged, imprisoned, and after their release; and the pursual of 'conspiracy to blackmail' charges against activists. The use of these malleable 'conspiracy to...' charges allowed the police and Crown Prosecution Service to successfully prosecute a wider range of activists. SHAC came to an end in 2014, after 13 activists were imprisoned as result of a long-term police investigation. Seven of these activists have since launched a campaign against what they regard as their wrongful imprisonment, arguing they were 'wrongfully convicted in a politically motivated miscarriage of justice' (SHAC Justice 2021).

Police have been transparent about their political prioritisation of the total elimination of SHAC. According to John Donovan, a Metropolitan Police Service officer, 'the police investigation and Crown Prosecution teams worked collaboratively, opting for an investigative strategy based on conspiracy to blackmail and leadership decapitation, rather than viewing all incidents as separate criminal acts' (Donovan and Coupe 2013: 127). 'Leadership decapitation' is a tactic traditionally rooted in responses to terrorist and organised crime groups (Johnston 2012). While police justified this as helping to prevent further crime and 'extremism', it ultimately functioned to uphold the ecologically destructive right to kill and to exploit animals in SHAC labs and more broadly. The violence animals face is legal, and endures, largely unacknowledged. SHAC briefly posed a challenge to state-corporate power and the dominant social-ecological order. In eliminating SHAC's campaign altogether, the suffering of animals in HLS labs was able to continue unchecked. In this sense, policing served to protect and uphold existing relations of animal exploitation, and therefore, environmental injustice more broadly.

\section{Conclusion - abolitionism for EJ!}

We have argued that environmental and climate justice approaches must understand the role of policing in producing harmful and deep-rooted social-ecological hierarchies. This should be understood in the context of contemporary policing's historical connection to and development from the policing of colonial extraction, slavery, and plantations. Policing has historically been central to securing hierarchies of domination, subordination, and exploitation of humans, non-humans, and ecosystems alike (Brock and Stephens-Griffin, forthcoming). Policing is a tool of the state, and maintains a capitalist social order, but it also plays a key role in enforcing ecological devastation and a separation between humans, non-humans, and nature. Rather than simply seeking to distribute environmental harms more evenly across populations, EJ scholars should therefore be questioning the very nature of ownership, 
questioning the notion of nature and animals as property, and questioning hegemonic anthropocentric modes of thinking and how these connect to logics of white, male supremacy. Crucially, that involves questioning the nature of policing and working towards abolitionist futures and alternatives, within EJ.

As activists and scholars have consistently demonstrated, environmental problems disproportionately impact and harm indigenous communities and communities of colour, compounding, entrenching, and exacerbating uneven social dynamics - a phenomenon Bullard (1993) famously called 'environmental racism'. Scholars such as Heynen and Ybarra (2021) have recently begun to draw connections between EJ and abolition, particularly via the concept of 'abolition ecology', which highlights the racialised processes underpinning environmental injustice. To apply abolitionism in EJ terms therefore means transforming the social-ecological conditions under which policing is presented as a 'solution' to the problems stemming from an unjust social order that it actually serves to maintain. These problems are rooted in damaging human/nature, human/non-human hierarchies which in turn help to justify and perpetuate these unjust environmental relations. Abolition means challenging the carceral logics that underpin this social order. In making alliances with abolitionist struggles, and in explicitly working towards abolitionist goals, EJ scholars and activists alike can help to address the pernicious yet vital role that policing plays in upholding environmental and climate injustice globally, and all the harmful hierarchies therein. We must move beyond the aim of redistributing harms and resources, towards challenging the very logics underpinning this ecocidal social order, within which policing is centrally important. EJ therefore necessitates abolition.

\section{Authors}

Andrea Brock is a political ecologist and political economist, and lecturer in International Relations at the University of Sussex, UK. She researches corporate power, state violence, and mining/ infrastructure projects. She is particularly interested in the repression, policing, and co-optation of environmental defenders, and how corporate and state actors manage resistance and engineer consent. Andrea's recent work develops an anarchist political ecology approach to fracking and coal mining, and a critique of 'green extractivism'. She is engaged in a number of environmental and social justice campaigns.

Nathan Stephens-Griffin is a senior lecturer at Northumbria University, UK. He works across the disciplines of sociology, criminology, and critical animal studies. His most recent research focuses on state/corporate repression of social movements, particularly the undercover policing of ecological protest. Nathan is also interested in biographical, visual, and graphic narrative approaches to social research. He is the author of Understanding Veganism: Biography and Identity (2017, Palgrave Macmillan). 


\section{Notes}

* This article would not exist in its current form without the contribution of Tom Anderson who read an initial draft and offered thoughtful and detailed critical feedback which helped expand and develop the work greatly. We would also like to thank Amber Huff for her contribution to our thinking in relation to this topic. Finally, we would like to thank our anonymous peer reviewer for their detailed and constructive feedback.

1 For the purpose of this article, we include climate justice under the broader umbrella of environmental justice. While important differences exist, they are less relevant for our argument.

2 See Braz and Gilmore (2006) for a notable exception.

3 For a longer exploration of the arguments presented in this article see Brock and Stephens-Griffin (forthcoming).

4 Another important dimension of policing is self-policing, for instance through the no-violence doctrine, which we cannot explore here for reasons of space (see Brock and Stephens-Griffin, forthcoming).

5 Importantly, not all environmental defenders involved in environmental/land/resource struggles would identify these as environmental justice struggles, and we do not want to impose this label.

$6 \mathrm{MONUSCO}$ is the acronym for the United Nations Organization Stabilization Mission in the Democratic Republic of the Congo, based on its French name.

\section{See Stop the JNF.}

\section{References}

Abrahamsen, R. and Williams, M.C. (2011) Security Beyond the State: Private Security in International Politics, Cambridge and New York NY: Cambridge University Press

Acosta, A. (2013) 'Extractivism and Neoextractivism: Two Sides of the Same Curse', in M. Lang and D. Mokrani (eds), Beyond Development: Alternative Visions from Latin America, trans. by S. Shields and R. Underhay, Quito and Amsterdam: Fundación Rosa Luxemburg and Transnational Institute

Álvarez, L. and Coolsaet, B. (2020) 'Decolonizing Environmental Justice Studies: A Latin American Perspective', Capitalism Nature Socialism 31.2: 50-69, DOI: 10.1080/10455752.2018.1558272 (accessed 26 October 2021) Arendt, H. (1951) The Origins of Totalitarianism, London: Penguin Argenti, N. and Knight, D.M. (2015) 'Sun, Wind, and the Rebirth of Extractive Economies: Renewable Energy Investment and Metanarratives of Crisis in Greece', Journal of the Royal Anthropological Institute 21.4: 781-802

Ashaba, I. (2020) 'Historical Roots of Militarised Conservation: The Case of Uganda', Review of African Political Economy 48.168: $276-88$

Avila-Calero, S. (2017) 'Contesting Energy Transitions: Wind Power and Conflicts in the Isthmus of Tehuantepec', Journal of Political Ecology 24.1: 992-1012 
BBC News (2014) 'HLS Animal Rights Blackmail: Woman Denies

Shac Plot', 24 February (accessed 22 October 2021)

BBC News (2001) 'Jail for Lab Boss Attacker', 16 August (accessed 22 October 2021)

Bookchin, M. (1982) The Ecology of Freedom: The Emergence and Dissolution of Hierarchy, Palo Alto CA: Cheshire Books

Bowling, B.; Reiner, R. and Sheptycki, J.W.E. (2019) The Politics of the Police, 5th ed., Oxford: Oxford University Press

Braz, R. and Gilmore, C. (2006) 'Joining Forces: Prisons and Environmental Justice in Recent California Organizing', Radical History Review 96: 95-111

Brock, A. (2020) ' "Frack Off": Towards an Anarchist Political Ecology Critique of Corporate and State Responses to Anti-Fracking Resistance in the UK', Political Geography 82: 102246

Brock, A. and Dunlap, A. (2018) 'Normalising Corporate Counterinsurgency: Engineering Consent, Managing Resistance and Greening Destruction around the Hambach Coal Mine and Beyond', Political Geography 62: 33-47

Brock, A. and Stephens-Griffin, N. (forthcoming) 'Policing Ecocide', in S. Springer and R. White (eds), Anarchist Currents Against Brutality

Brogden, M. (1987) 'The Emergence of the Police - The Colonial Dimension', British Journal of Criminology 27.1: 4-14

Bullard, R.D. (ed.) (1993) Confronting Environmental Racism: Voices from the Grassroots, Boston MA: South End Press

Carruthers, D. and Rodríguez, P. (2009) 'Mapuche Protest, Environmental Conflict and Social Movement Linkage in Chile', Third World Quarterly 30.4: 743-60

Chowdhury, T. (2021) 'From the Colony to the Metropole: Race, Policing and the Colonial Boomerang', in K. Duff (ed.), Abolishing the Police, London: Dog Section Press

Cohen, M. (2017) 'Animal Colonialism: The Case of Milk', AJIL Unbound 111: 267-71

Covert Human Intelligence Sources (Criminal Conduct) Act 2021 (accessed 12 October 2021)

Cudworth, E. (2015) 'Killing Animals: Sociology, Species Relations and Institutionalized Violence', Sociological Review 63.1: 1-18

Dalton, J. (2021) 'Meat-Eating Creates Risk of Future Pandemic that "Would Make Covid Seem a Dress Rehearsal", Scientists Warn', The Independent, 30 January (accessed 9 September 2021)

Davis, A.Y. (2005) Abolition Democracy: Beyond Prison, Torture and Empire, New York NY: Seven Stories Press

Donovan, J. and Coupe, R.T. (2013) 'Animal Rights Extremism: Victimization, Investigation and Detection of a Campaign of Criminal Intimidation', European Journal of Criminology 10.1: $113-32$

Duffy, R. (2016) 'War, by Conservation', Geoforum 69: 238-48

Dunlap, A. (2021) 'Toward an Anarchist Decolonization: A Few Notes', Capitalism Nature Socialism (advance online publication) 
Dunlap, A. (2020) 'Compost the Colony: Exploring Anarchist Decolonization', Tvergastein Journal 15.1: 1-6

Dunlap, A. (2019) Renewing Destruction: Wind Energy Development, Conflict and Resistance in a Latin American Context, London: Rowman \& Littlefield

Dunlap, A. (2014) 'Permanent War: Grids, Boomerangs, and Counterinsurgency', Anarchist Studies 22.2: 55-79

EJ Atlas (2021) Environmental Justice Atlas (accessed 22 October 2021)

Elliott-Cooper, A. (2021) Black Resistance to British Policing, Manchester: Manchester University Press

Express \& Star (2017) 'Anti-Poaching Project Backed by Charles's Charity Announced at Wildlife Summit', Express \& Star, 4 November (accessed 28 June 2021)

Forces Net (2018) 'UK Military to Develop Anti-Poaching Force With $£ 900 \mathrm{k}$ of New Funding', 11 October (accessed 28 June 2021)

Foucault, M. (2007) Security, Territory, Population: Lectures at the Collège de France 1977-1978, trans. by G. Burchell (2007 ed.), London and New York NY: Palgrave Macmillan

G4S (2020) Activist Bulletin January, London: G4S (accessed 22 October 2021)

Gelderloos, P. (2007) How Nonviolence Protects the State, Boston MA: South End Press

Gillespie, K. and Narayan, Y. (2020) 'Animal Nationalisms: Multispecies Cultural Politics, Race, and the (Un)Making of the Settler Nation-State', Journal of Intercultural Studies 41.1: 1-7

Griffin, J. (2020) 'Police Accused of Unprovoked Assault on HS2 Protester', The Guardian, 10 October (accessed 9 September 2021)

Grossi, G.; Goglio, P.; Vitali, A. and Williams, A.G. (2019) 'Livestock and Climate Change: Impact of Livestock on Climate and Mitigation Strategies', Animal Frontiers 9.1: 69-76

Heynen, N. and Ybarra, M. (2021) 'On Abolition Ecologies and Making "Freedom as a Place"', Antipode 53.1: 21-35

HS2 (2021) Responsible Business and the Environment (accessed 12 October 2021)

Huff, A. and Orengo, Y. (2020) 'Resource Warfare, Pacification and the Spectacle of "Green" Development: Logics of Violence in Engineering Extraction in Southern Madagascar', Political Geography 81: 102195

Inquest (2020) Deaths in Police Custody (accessed 9 September 2021)

Johnson, W. (2013) River of Dark Dreams: Slavery and Empire in the Cotton Kingdom, Cambridge MA: Belknap Press

Johnston, P.B. (2012) 'Does Decapitation Work? Assessing the Effectiveness of Leadership Targeting in Counterinsurgency Campaigns', International Security 36.4: 47-79

Joseph-Salisbury, R.; Connelly, L. and Wangari-Jones, P. (2021) " "The UK is Not Innocent": Black Lives Matter, Policing and Abolition in the UK', Equality, Diversity and Inclusion 40.1: 21-28 
Kaba, M. (2021) We Do This 'Til We Free Us, Chicago IL: Haymarket Books

Kappeler, V.E. (2014) 'A Brief History of Slavery and the Origins of American Policing', Eastern Kentucky University, 7 January (accessed 22 September 2021)

Kill, J. and Franchi, G. (2016) Rio Tinto's Biodiversity Offset in Madagascar: Double Landgrab in the Name of Biodiversity? World Rainforest Movement and Re:Common

Lamble, S. (2021) 'Practicing Everyday Abolition', in K. Duff (ed.), Abolishing the Police, London: Dog Section Press

Losasso, C. et al. (2018) 'Assessing Antimicrobial Resistance Gene Load in Vegan, Vegetarian and Omnivore Human Gut Microbiota', International Journal of Antimicrobial Agents 52.5: 702-5

Lubbers, E. (2012) Secret Manoeuvres in the Dark: Corporate and Police Spying on Activists, London: Pluto Press

Mansell, P. (2009) 'Life Sciences Research Goes Private for US\$8.50 Per Share', PharmaTimes, 13 July (accessed 28 June 2021)

Mason, K. and Askins, K. (2012) ' "Us and Us": Faslane 30 and Academic Direct Action', Medicine, Conflict and Survival 28.4: 282-88

Maxwell-Stewart, H. (2010) 'Convict Transportation from Britain and Ireland 1615-1870', History Compass 8.11: 1221-42

McGinnis, A. (1990) Counting Coup and Cutting Horses: Intertribal Warfare on the Northern Plains, 1738-1889, Evergreen CO: Cordillera Press

Milmo, C.; Heal, A. and Wasley, A. (2018) 'Revealed: Heavy Toll of Injury Suffered by Slaughter Workers in Britain's $£ 8$ bn Meat Industry', iNews, 29 July (accessed 2 September 2021)

Minarchek, M. (2020) 'Creating Environmental Subjects: Conservation as Counter-Insurgency in Aceh, Indonesia, 1925-1940', Political Geography 81: 102189

MoD (2019) 'British Forces Support Gabon's Fight against Elephant Poachers', 28 April (accessed 22 October 2021)

N1M (2020) UK (accessed 12 October 2021)

Neocleous, M. (2021) A Critical Theory of Police Power, London: Verso Neumann, R.P. (2004) 'Moral and Discursive Geographies in the War for Biodiversity in Africa', Political Geography 23.7: 813-37

Nibert, D. (ed.) (2017) Animal Oppression and Capitalism [2 volumes], Santa Barbara CA: ABC-CLIO

Nurse, A. (2013) 'Species Justice: The Future Protection of Wildlife and the Reform of Wildlife Laws', Green Criminology Monthly 6: $1-11$

Pellow, D.N. (2014) Total Liberation: The Power and Promise of Animal Rights and the Radical Earth Movement, Minneapolis MN: University of Minnesota Press

Perkins, T. (2021) 'The Multiple People of Color Origins of the US Environmental Justice Movement: Social Movement Spillover and Regional Racial Projects in California', Environmental Sociology 7.2: 147-59, DOI: 10.1080/23251042.2020.1848502 (accessed 26 October 2021) 
Posłuszna, E. (2015) Environmental and Animal Rights:

Extremism, Terrorism, and National Security, London:

Butterworth-Heinemann

Pulido, L. and De Lara, J. (2018) 'Reimagining "Justice" in

Environmental Justice: Radical Ecologies, Decolonial Thought, and the Black Radical Tradition', Environment and Planning E: Nature and Space 1.1-2: 76-98

Quijano, A. (2000) 'Coloniality of Power and Eurocentrism in Latin America', International Sociology 15.2: 215-32

Radford, J. and Stanko, E.A. (1994) 'The Contradictions of Patriarchal Crime Control', Peace Review: A Journal of Social Justice 6.2: 149-58

Rahim, Z. (2018) 'Police Force Admits Passing Disabled Anti-Fracking Protesters' Details to DWP', The Independent, 24 December (accessed 9 September 2021)

Ramakrishna, K. (2014) 'The Police Must be Part of the People and the People Part of the Police', in C. Christine Fair and S. Ganguly (eds), Policing Insurgencies: Cops as Counterinsurgents, New Delhi: Oxford University Press

Redfield, P. (2005) 'Foucault in the Tropics: Displacing the Panopticon', in J. Xavier Inda (ed.), Anthropologies of Modernity: Foucault, Governmentality, and Life Politics, Oxford: Blackwell Publishing

Reiner, R. (2010) The Politics of the Police, 4th ed., Oxford: Oxford University Press

Roy, A. (2021) 'Undoing Property: Feminist Struggle in the Time of Abolition', Society + Space, 3 May (accessed 9 September 2021)

Scheidel, A. et al. (2020) 'Environmental Conflicts and Defenders: A Global Overview', Global Environmental Change 63: 102104

Scott, J.C. (1998) Seeing Like a State: How Certain Schemes to Improve the Human Condition Have Failed, New Haven CT and London: Yale University Press

Selwyn, D. (2020) Martial Mining: Resisting Extractivism and War Together, London: London Mining Network

SHAC Justice (2021) The Power of Protest is Under Attack (accessed 22 October 2021)

Siamanta, Z.C. (2019) 'Wind Parks in Post-Crisis Greece: Neoliberalisation vis-à-vis Green Grabbing', Environment and Planning E: Nature and Space 2.2: 274-303

Sinclair, G. and Williams, C.A. (2007) ' "Home and Away": The Cross-Fertilisation Between "Colonial" and "British" Policing, 1921-85', Journal of Imperial and Commonwealth History 35.2: 221-38

Sovacool, B.K. (2021) 'Who are the Victims of Low-Carbon Transitions? Towards a Political Ecology of Climate Change Mitigation', Energy Research and Social Science 73: 101916

Stephens-Griffin, N.; Lampkin, J.; Wyatt, T. and Stephenson, C. (2021) ' "It Often Feels Like You Are Talking to A Wall": Police and Private Security Responses to the Campaign to Protect Pont Valley Against Opencast Coal Extraction', Critical Criminology 29.2: 199-214 
Stephenson, M. (2021) 'More than 100 Women Accuse Police Officers of Domestic Abuse, Alleging "Boys Club" Culture', Channel 4 News, 18 May (accessed 28 June 2021)

Taylor, D. (2021) 'HS2 Protesters Hope to Occupy Euston Tunnel for Weeks', The Guardian, 27 January (accessed 9 September 2021)

Temper, L. et al. (2020) 'Movements Shaping Climate Futures: A Systematic Mapping of Protests against Fossil Fuel and Low-Carbon Energy Projects', Environmental Research Letters 15.12: 1-23

Thompson, K. (2018) 'Prisons, Policing, and Pollution: Toward an Abolitionist Framework within Environmental Justice', Pomona Senior Theses 185, Claremont CA: Pomona College laccessed 9 September 2021)

Townsend, M. and Heal, A. (2019) 'Domestic Abuse within Police Force to be Investigated', The Guardian, 20 October (accessed 9 September 2021)

Twine, R. (2012) 'Revealing the "Animal-Industrial Complex": A Concept and Method for Critical Animal Studies?', Journal for Critical Animal Studies 10.1: 12-39

UK Government (2015) Counter-Terrorism and Security Act Collection (accessed 9 September 2021)

Various (2014) Black Seed Issue 1 (accessed 9 September 2021)

Verweijen, J. and Dunlap, A. (2021) 'The Evolving Techniques of the Social Engineering of Extraction: Introducing Political (Re)actions "from Above" in Large-Scale Mining and Energy Projects', Political Geography 88: 102342

Vitale, A.S. (2017) The End of Policing, London: Verso

Whitehouse, D. (2014) 'Origins of the Police', Works in Theory, 7 December (accessed 19 June 2020)

Willow, A.J. (2016) 'Indigenous ExtrACTIVISM in Boreal Canada: Colonial Legacies, Contemporary Struggles and Sovereign Futures', Humanities 5.3: 55-70

Woodman, C. (2020) How British Police and Intelligence are a Product of the Imperial Boomerang Effect, Verso Blog, 10 June (accessed 12 November 2020)

Wyatt, T. (2009) 'Exploring the Organization of Russia Far East's Illegal Wildlife Trade: Two Case Studies of the Illegal Fur and Illegal Falcon Trades', Global Crime 10.1-2: 144-54 